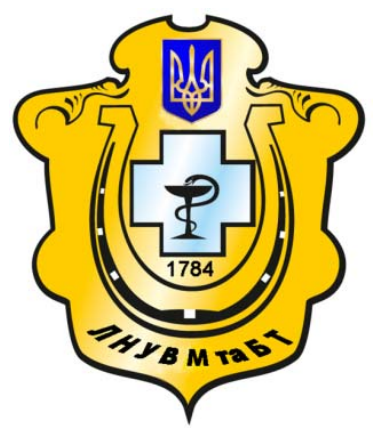

Науковий вісник Львівського національного університету ветеринарної медицини та біотехнологій імені С.3. Гжицького

Scientific Messenger of Lviv National University of Veterinary Medicine and Biotechnologies named after S.Z. Gzhytskyj

doi:10.15421/nvlvet6909

ISSN 2413-5550 print

ISSN 2518-1327 online

http://nvlvet.com.ua/

УДК: 339.9: 636:3

\title{
Основи ефективності сільськогосподарських підприємств вівчарства і козівництва
}

\author{
М.Л. Диндин, О.П. Токарчук \\ Dyndynmisha@mail.ru
}

\begin{abstract}
Львівський національний університет ветеринарної медицини та біотехнологій імені С.3. Гжицького, вул. Пекарська, 50, м. Львів, 79010, Украӥна
\end{abstract}

\begin{abstract}
Історично вівчарство є традиџійною галуззю сільськогосподарського виробництва в Україні. У процесі розвитку вівчарства і козівництва створено галузь з багатим генофондом. Однак з переходом на ринкові відносини нагромаджений потенціал галузі почав руйнуватися. Наразі гострою вбачається необхідність відродження вівчарства $і$ козівництва у сільськогосподарських підприємствах, щзо вимагає розширення наукових досліджень щодо забезпечення ефективного ведення галузі, формування конкурентоспроможної продукиії вівчарства і козівництва. Обтрунтування напрямів успішного вирішення цього завдання можливе лише за умови об'єктивної всебічної оцінки стану розвитку вівчарства і козівництва в сільськогосподарських підприємствах та рівня ефективності виробництва продукції галузі. Розглянуто теоретичні основи ефективності сільськогосподарських підприємств вівчарства і козівництва в ринкових умовах господарювання. Проаналізовано існуючі на сьогодні визначення категорії «ефективність». Висвітлено концепиії аналізу ефективності підприємницької діяльності та рівень економічної ефективності сільськогосподарських підприсмств вівчарства і козівництва. Визначено показники ефективного виробництва у вівчарстві та козівництві. Відображено фактори формування ефективності сільськогосподарських підприємств вівчарства і козівництва. Розкрито поняття «ефективність» різними економістамиаграрниками у науковій літературі. Проілюстровано систему чинників зростання ефективності виробництва продукиї вівчарства і козівничтва у сільськогосподарських підприємствах.
\end{abstract}

Ключові слова: вівчарство, козівництво, сільськогосподарські підприємства, ефективність.

\section{Основы эффективности сельскохозяйственных предприятий овцеводства и козоводства}

\author{
М.Л. Дындын, О.П. Токарчук \\ Dyndynmisha@mail.ru
}

\begin{abstract}
Львовский национальный университет ветеринарной медицины и биотехнологий имени С.3. Гжицкого, ул. Пекарская, 50, г. Львов, 79010, Украина
\end{abstract}

\begin{abstract}
Исторически овцеводство является традиционной отраслью сельскохозяйственного производства в Украине. В процессе развития овцеводства и козоводства создано отрасль с богатым генофондом. Однако с переходом на рыночные отношения накопленный потенциал отрасли начал разрушаться. Сейчас острой усматривается необходимость возрождения овиеводства и козоводства в сельскохозяйственных предприятиях, требует расширения научных исследований по обеспечению эффективного ведения отрасли, формирования конкурентоспособной продукиии овиеводства и козоводства. Обоснование направлений успешного решения этой задачи возможно лишь при условии объективной всесторонней оценки состояния развития овиеводства и козоводства в сельскохозяйственных предприятиях и уровня эффективности производства продукции отрасли. Рассмотрены теоретические основы эффективности сельскохозяйственных предприятий овиеводства и козоводства в рыночных условиях хозяйствования. Проанализированы существующие на сегодня определения категории «эффективность». Освещены конщепџии анализа эффективности предпринимательской деятельности и уровень экономической эффективности сельскохозяйственных предприятий овиеводства и козоводства. Определены показа-
\end{abstract}

Citation:

Dyndyn, M., Tokarchuk, O. (2016). Basis of the effectiveness of agricultural enterprises sheep and goat. Scientific Messenger LNUVMBT named after S.Z. Gzhytskyj, 18, 2(69), 53-57. 
тели эффективного производства в овцеводстве и козоводстве. Отражено факторь формирования эффективности сельскохозяйственных предприятий овцеводства и козоводства. Раскрыто понятие «эффективность» различныли экономистами-аграриями в научной литературе. Проиллюстрировано систему факторов роста эффективности производства продукции овцеводства и козоводства в сельскохозяйственных предприятиях.

Ключевые слова: овцеводство, козоводство, сельскохозяйственные предприятия, эффективность.

\title{
Basis of the effectiveness of agricultural enterprises sheep and goat
}

\author{
M. Dyndyn, O. Tokarchuk \\ Dyndynmisha@mail.ru \\ Lviv National University of Veterinary Medicine and Biotechnologies named after S.Z. Gzhytskyi, \\ Pekarska Str., 50, Lviv, 79010, Ukraine
}

\begin{abstract}
Historically, the sheep is a traditional sector of agricultural production in Ukraine. In the development of sheep and kozivnytstva established industry with a rich gene pool. However, with the transition to market relations accumulated potential of the industry began to crumble. Currently seen acute need revival and sheep kozivnytstva in agricultural enterprises requiring expansion of research to ensure effective management of the industry, the formation of competitive products and kozivnytstva sheep. Justification directions successful solution to this problem is possible only if the objective of a comprehensive assessment of the development of sheep and kozivnytstva agricultural enterprises and the efficiency of the production area. The theoretical principles of efficiency of agricultural enterprises sheep and goat under market conditions. Existing today the definition of "efficiency". Deals with the concept of analyzing the efficiency of business and the level of economic efficiency and sheep farms kozivnytstva. Indices effective production in sheep and kozivnytstvi. Showing factors of efficiency and sheep farms kozivnytstva. The notion of "efficiency" various agricultural economists in the scientific literature. Illustrated system factors increase the efficiency of production of sheep and kozivnytstva agricultural enterprises.
\end{abstract}

Key words: sheep, goat, farms, efficiency.

\section{Ветуп}

Серед важливих проблем економіки будь-якого підприємства центральною завжди була і залишається проблема збереження його існування в довгостроковому періоді як самостійного суб'єкта господарювання. Досягти цього можливо лише за умови забезпечення конкурентоспроможного, ефективного виробництва.

Проаналізувавши існуючі на сьогодні визначення категорії «ефективність», можна виділити два основні підходи. Перший підхід характеризує «ефективність» в значенні результативність, тобто відповідає на питання які результати досягнуті і за яку ціну, які і скільки ресурсів було витрачено на досягнення отриманих результатів. В цьому підході ефективність розглядається як співвідношення результатів та витрат. Критеріями першого підходу є «витрати-результат». Але постає питання чи надасть нам отриманий результат можливість досягти мети, наскільки близько ми до досягнення мети. Наявність цих питань обумовила існування другого підходу, який характеризує «ефективність» 3 позиції досягнення мети, він відповідає на питання чи досягли ми поставленої мети, наскільки ми до неї наблизились. Критеріями цього підходу є «результат-мета» (Mejer, 2004; Voronenko et al., 2007; Gorbonos et al., 2010).

Meта cmammi. Опрацювати теоретичні основи ефективності сільськогосподарських підприємств вівчарства і козівництва в ринкових умовах господарювання.

\section{Матеріал і методи досліджень}

Теоретичні та практичні аспекти ефективного функціонування й розвитку вівчарства і козівництва у сільськогосподарських підприємствах знайшли своє відображення в працях вітчизняних та зарубіжних економістів-аграрників: Б.Б. Батюка, Б.О. Вовченка, В.В. Зіновчука, Л.В. Жаруна, Р.М. Миніва, Г.І. Сокола, В.В. Стороженка, І.Н. Топіхи, В.П. Тараненка та ін. Ними розроблені теоретичні, методологічні та прикладні основи вдосконалення організаційноекономічного механізму функціонування галузі. Однак існуючі тенденції в іiі розвитку свідчать про необхідність продовження наукових розвідок у цій сфері.

\section{Результати та їх обговорення}

Однією з найпопулярніших у зарубіжних концепціях аналізу ефективності підприємницької діяльності $\epsilon$ концепція збалансованої системи показників (Balanced Scorecard, BSC), розроблена на початку 1990-х років Робертом Капланом і Девідом Нортоном. Для вирішення проблеми оцінки ефективності BSC передбачає використання ряду нових індикаторів поряд 3 традиційними і поділяє всю систему оцінки діяльності компанії на чотири групи: фінанси; клієнти; внутрішні бізнес-процеси; навчання і розвиток персоналу. Особливістю розробленої системи оцінки ефективності є застосування не лише фінансових показників (які $\epsilon$ традиційними та пропонуються більшістю методик і рекомендацій), але й не фінансових, що оцінюють задоволеність покупців та акціонерів, ефективність внутрішніх бізнес процесів, потенціал співробітників 3 метою забезпечення довгострокового фінансового успіху компанії.

В загальному рівень економічної ефективності сільськогосподарських підприємств вівчарства і козівництва визначається як співвідношення результату до витрат або до ресурсів. Підвищення ефективності може досягатися як за рахунок зменшення витрат 
(економії ресурсів), так і за рахунок покращення використання капіталу і збільшення прибутку. Такий підхід передбачає наявність протиріччя: основною метою діяльності є максимізація результату (ефекту); при обмеженості ресурсів та високій їх вартості необхідно досягати раціонального зменшення їх використання.

Ефективність виробництва у вівчарстві характеризується такими показниками, як продуктивність тварин, тобто середньодобові прирости, настриг вовни на 1 гол., витрати кормів характеризують продуктивність худоби і кормового забезпечення. Цей показник ще називають «оплата корму продукцією». Матеріаломісткість виробництва характеризує рівень продуктивності галузі. Економічний бік вівчарства характеризують наступні показники: повна собівартість 1 ц продукції, прибуток і рівень рентабельності (Smola, 2011).

Сучасний міжнародний стандарт ISO: 9000:2000, розглядає ефективність як співвідношення між досягнутим результатом і використаними ресурсами, що свідчить про ресурсний підхід до визначення категорії «ефективність».

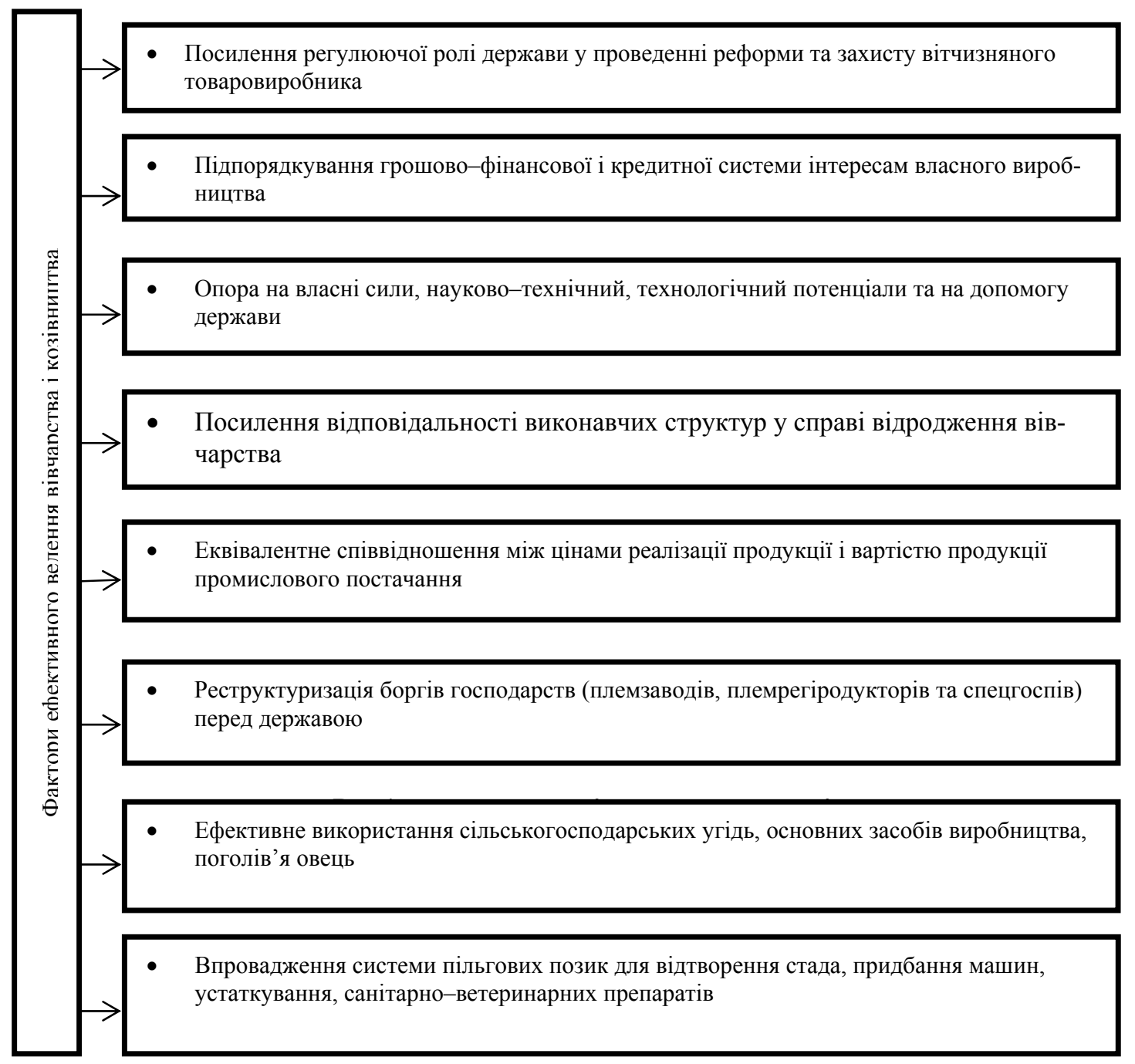

Рис. 1. Ефективність сільськогосподарських підприємств вівчарства і козівництва формуються під дією багатьох різноманітних факторів

Джерело: власні дослідження

Ефективність вівчарства і козівництва залежить також від видів тварин, їхнього продуктивного потенціалу, адаптації до конкретних умов розведення, селекції, застосування нових технологій, якості продукції, повноти їі використання.

Визначення поняття «ефективність» різними авторами подано в таблиці 1.

Рівень економічної діяльності підприємства залежить від багатьох чинників і умов. Ці чинники в реа- льності діють не ізольовано, в чистому вигляді, а здебільшого перетинаються і взаємозумовлюють один одного. Частина з них залежить від діяльності підприємства загалом, інші пов'язані з технологією й організацією виробництва, а ще деякі зумовлені рівнем використання виробничих ресурсів і впровадженням науково-технічного прогресу. Всі чинники зростання ефективності можна класифікувати за трьома ознаками (рис. 2). 
Визначення поняття «ефективність» різними авторами

\begin{tabular}{|c|c|}
\hline Автор & Поняття \\
\hline Сурмін Ю.П. & $\begin{array}{l}\text { Ефективність показник успішності функціонування системи для досягнення встановлених } \\
\text { цілей. }\end{array}$ \\
\hline Орлов П.А. & $\begin{array}{l}\text { Ефективність співвідношення результату або ефекту будь-якої діяльності і витрат, } \\
\text { пов'язаних з тї виконанням. Причому це може бути як співвідношення результату і витрат, } \\
\text { так і співвідношення і результатів діяльності. }\end{array}$ \\
\hline $\begin{array}{l}\text { Нусінов В.Я., } \\
\text { Турило А.М., } \\
\text { Темченко А.Г. }\end{array}$ & $\begin{array}{l}\text { Ефективність є результативність, тобто результат діяльності (ефект), який одержує суспіль- } \\
\text { ство, підприємство або окрема людина на одиницю використаних (чи застосованих) ресур- } \\
\text { сів. }\end{array}$ \\
\hline $\begin{array}{l}\text { Лямець В.І., } \\
\text { Тевяшев А.Д. }\end{array}$ & $\begin{array}{l}\text { Ефективність це не просто властивість операції (процесу функціонування системи), що } \\
\text { відбивається в ії здатності давати певний ефект, а дієвість такої здатності, тобто результати- } \\
\text { вність, співвіднесена } 3 \text { ресурсними витратами. }\end{array}$ \\
\hline Сініцина Т.А. & Ефективність це співвідношення ефекту та витрат на його здійснення. \\
\hline Устенко О.Л. & $\begin{array}{l}\text { Ефективність являє собою комплексне вираження кінцевих результатів використання засо- } \\
\text { бів виробництва та робочої сили за певний період часу. }\end{array}$ \\
\hline $\begin{array}{l}\text { Шеремет А.Д., } \\
\text { Сайфулін Р.С. }\end{array}$ & $\begin{array}{l}\text { Ефективність це складна категорія, що характеризується результативністю роботи підпри- } \\
\text { ємства та рентабельністю його капіталу, ресурсів або продукції. }\end{array}$ \\
\hline Друкер П.Ф. & Ефективність це наслідок того, що «правильно створюються потрібні речі». \\
\hline
\end{tabular}

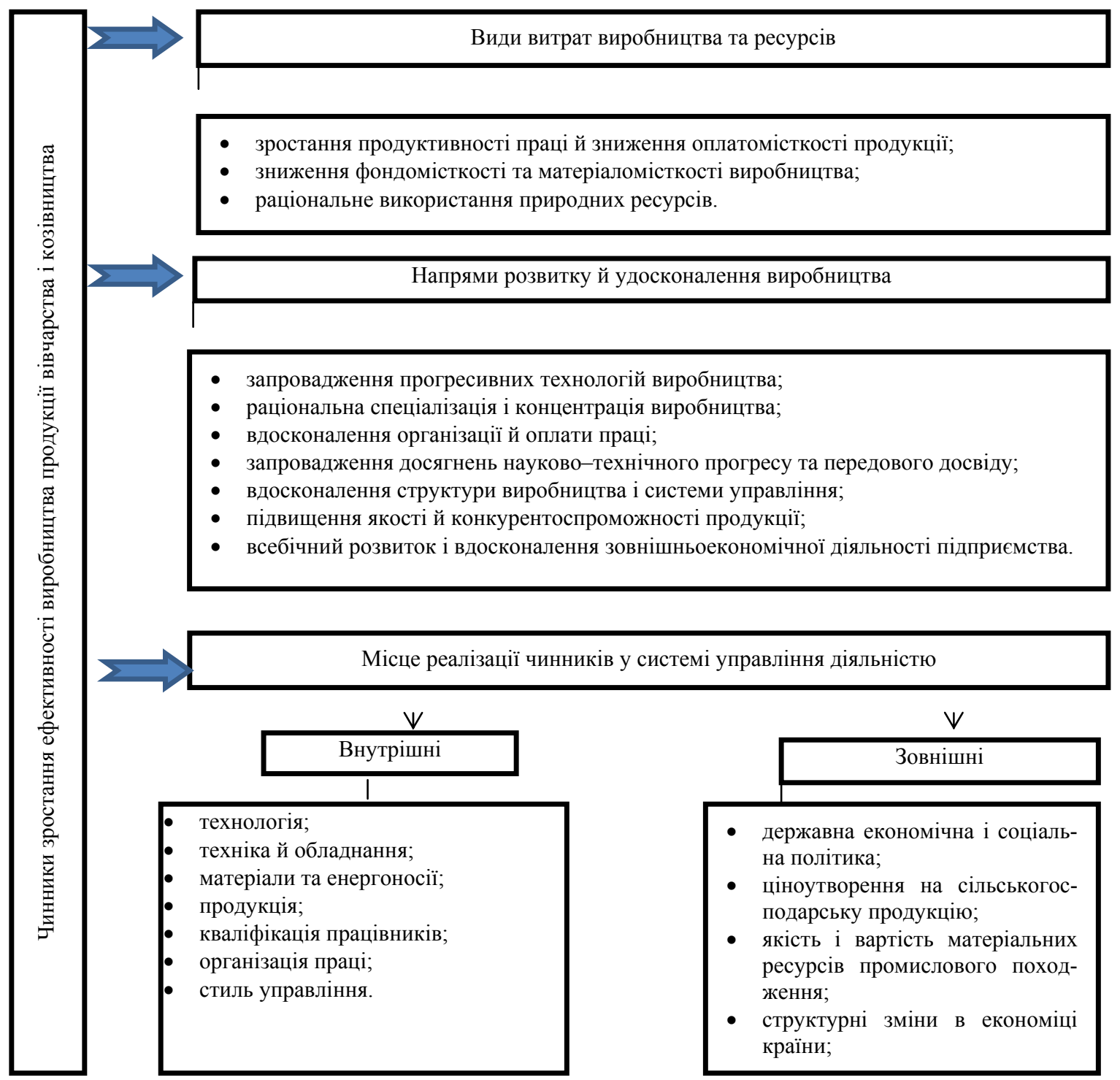

Рис. 2. Система чинників зростання ефективності виробництва продукції вівчарства і козівництва Джерело: власні дослідження. 


\section{Висновки}

Отже, ефективність господарської діяльності сільськогосподарських підприємств вівчарства і козівництва - сформована система господарювання, в якій сконцентровані всі необхідні для цього фактори від виробничих ресурсів до механізмів господарювання. Що забезпечує виробництво максимальної кількості високоякісної продукції при найменших витратах ресурсів, досягаючи при цьому найбільшого обсягу виробництва продукції на одиницю витрат суспільної праці. Найкращі можливості для виробництва і реалізації продукції вівчарства і козівництва з метою досягнення максимального прибутку від господарської діяльності є спроможність суб'єктів господарювання приводити в дію наявні чинники виробництва і комплексно вирішувати питання раціонального використання трудових, земельних, матеріальних і фінансових ресурсів.

\section{Бібліографічні посилання}

Smola, I.I. (2011). Pidvyshhennja efektyvnosti vivcharstva na pidpryjemstvah Hersons'koi' oblasti. Produktyvnist' agropromyslovogo vyrobnyctva. 20, 112-119 (in Ukrainian).

Mejer, M.V. (2004). Ocenka jeffektivnosti biznesa / Marshal V. Mejer: [per. s angl. A. O. Korsunskij]. M.: OOO «Vershina» (in Russian).

Voronenko, V.I., Iovenko, V.M., Zharuk, P.G. (2007). Vivcharstvo Ukrai'ny, stan ta perspektyvy rozvytku. Vivcharstvo: Mizhvidomchyj tematychnyj naukovyj zbirnyk. Nova Kahovka: «PYEL». 34, 3-7 (in Ukrainian).

Gorbonos, F.V., Cherevko, G.V., Pavlenchyk, N.F., Pavlenchyk, A.O. (2010). Ekonomika pidpryjemstv: Pidruch. K.: Znannja (in Ukrainian).

Стаття надійшла до редакиії 30.09.2016 